\title{
Joanna Olszewska-GNiadek
}

Uniwersytet Jagielloński

ORCID - 0000-0002-3853-6615

\section{DORADCA ZAWODOWY \\ W PORADNI PSYCHOLOGICZNO-PEDAGOGICZNEJ - JEGO KOMPETENCJE I ZADANIA}

Wprowadzenie: Poradnictwo edukacyjno-zawodowe ma w Polsce blisko stuletnią historię. Pierwsze poradnie powstawały już bowiem w dwudziestoleciu międzywojennym, a ich głównym zadaniem było udzielanie młodzieży wsparcia przy wyborze zawodu.

Cel badań: Celem tego opracowania jest prezentacja działalności doradcy zawodowego zatrudnionego w poradni psychologiczno-pedagogicznej. Artykuł ma charakter przeglądowy, a główny punkt ciężkości jest położony tutaj na osobę doradcy zawodowego (w kontekście wymagań formalnych do tego zawodu, tj. kwalifikacji, kompetencji, pożądanych cech osobowych), a także wytyczonych przez prawo oświatowe zadań, obszarów działań, treści, form, metod i narzędzi niezbędnych w pracy na tym stanowisku.

Stan wiedzy: Doradca zawodowy zatrudniony w poradni psychologiczno-pedagogicznej to specjalista z zakresu orientacji i poradnictwa zawodowego, świadczący pomoc uczniom szkół podstawowych i średnich w procesie planowania kariery edukacyjno-zawodowej. Jest to osoba o wysokich kwalifikacjach formalnych i kompetencjach (w zakresie wiedzy i umiejętności), obdarzona takimi pożądanymi cechami osobowymi, jak: otwartość, życzliwość, empatia, komunikatywność, cierpliwość. Proces doradczy opiera się na nawiązaniu pozytywnej relacji z klientem, rozpoznaniu zasobów jednostki (popartych badaniem diagnostycznym), a w konsekwencji wypracowaniu indywidualnego planu działania (IPD). Warsztat doradcy zawodu tworzony jest zgodnie z przepisami prawa oświatowego, stosownie do zróżnicowanych potrzeb i oczekiwań klientów. Podsumowanie: Wsparcie ucznia w wyborach edukacyjno-zawodowych czyni proces decyzyjny bardziej świadomym i przemyślanym, zwiększając tym samym szanse klienta na osiągnięcie sukcesu w przyszłej szkole i pracy. Działania doradcze z jednej strony mają swoją konkretną metodykę, z drugiej zaś są wykonywane w bardzo dynamicznej rzeczywistości. Wiedza, umiejętności i warsztat pracy tego specjalisty muszą być więc nieustannie poszerzane i aktualizowane, by jak najlepiej sprostać wyzwaniom współczesności.

Słowa kluczowe: doradca zawodowy, klient poradni, poradnictwo edukacyjno-zawodowe, proces wyboru zawodu, sukces zawodowy, wybory edukacyjno-zawodowe młodzieży 


\section{WPROWADZENIE}

Poradnictwo edukacyjno-zawodowe ma w Polsce blisko stuletnią historię. Pierwsze poradnie powstawały już bowiem w dwudziestoleciu międzywojennym, a ich głównym celem było udzielanie młodzieży wsparcia przy wyborze zawodu. W latach 50. (po przerwie w działalności przypadającej na okres II wojny światowej) placówki te włączono do systemu oświaty. Na początku funkcjonowały dwa typy poradni: wychowawcze i zawodowe, ale ze względu na utrudnienia natury organizacyjnej, problemy z ustaleniem zakresu ich kompetencji i funkcji w latach 60. nastąpiło ich połączenie. Powstały poradnie wychowawczo-zawodowe, co doprowadziło do zwiększenia roli poradnictwa w procesie edukacji oraz wzrostu liczby pracowników. W 1993 roku decyzją Ministra Edukacji Narodowej poradnie wychowawczo-zawodowe przekształcono w poradnie psychologiczno-pedagogiczne (Jaskulska, 2015).

Jak wynika z ustawy o systemie oświaty, poradnie zostały powołane do udzielania pomocy psychologiczno-pedagogicznej dzieciom, młodzieży, rodzicom i nauczycielom, w tym również dla wszechstronnego wsparcia uczniów w wyborze kierunku kształcenia i zawodu ${ }^{1}$. Z kolei rozporządzenie Ministra Edukacji Narodowej z 1 lutego 2013 r. w sprawie szczegółowych zasad działania publicznych poradni psychologiczno-pedagogicznych precyzuje, że pomoc ta jest adresowana nie tylko do konkretnych osób (uczniów, rodziców i nauczycieli), ale również do instytucji, tj. przedszkoli, szkół i placówek w zakresie realizacji zadań dydaktycznych, wychowawczych i opiekuńczych ${ }^{2}$. Poradnia jest więc jednym z elementów systemu oświaty, który w centrum zainteresowania stawia dziecko/ucznia, a którego działania są realizowane we współpracy z innymi podmiotami zaangażowanymi w proces jego rozwoju i wychowania (Olszewska-Gniadek, 2015).

\section{PROBLEM I CEL BADAŃ}

Celem niniejszego opracowania jest prezentacja działalności doradcy zawodowego zatrudnionego w poradni psychologiczno-pedagogicznej. Szczególnej analizie będą poddane wymagania formalne do tego zawodu, tj. kwalifikacje, kompetencje, po-

${ }^{1}$ Ustawa z dnia 7 września z 1991 r. o systemie oświaty - Dz. U. z 2020 r. poz. 1327 oraz z 2021 r. poz. 4 i 1237.

2 Rozporządzenie Ministra Edukacji Narodowej z dnia 1 lutego 2013 r. w sprawie szczegółowych zasad działania publicznych poradni psychologiczno-pedagogicznych, w tym publicznych poradni specjalistycznych (Dz. U. poz. 199 z późn. zm. - ostatnia nowelizacja z 2017 roku - patrz: Rozporządzenie Ministra Edukacji Narodowej z dnia 25 sierpnia 2017 r. (Dz.U. z 2017, poz. 1647). 
żądane cechy osobowe, a także wytyczone przez prawo oświatowe zadania, obszary działań, treści, formy, metody i narzędzia niezbędne w pracy na tym stanowisku.

Autorka na podstawie analizy aktów prawnych, literatury przedmiotu, doświadczeń własnych oraz informacji pozyskanych w wywiadach od innych doradców zatrudnionych w krakowskich poradniach psychologiczno-pedagogicznych stara się odpowiedzieć na następujące pytania: jakie są standardy wymagań do zawodu doradcy zawodowego? Jakie są główne zadania i obszary działań doradcy w poradni psychologiczno-pedagogicznej? Jakie grupy klientów są objęte działaniami poradni w zakresie doradztwa zawodowego? Jak przebiega proces wsparcia przez poradnię wyborów zawodowych młodzieży w szkołach podstawowych i średnich? $\mathrm{Z}$ jakich form, metod, narzędzi korzysta doradca zawodowy poradni? Jakie są możliwości optymalizacji świadczonych przez poradnię usług w zakresie doradztwa zawodowego?

Niniejsza publikacja ma również zachęcać do dyskusji na temat kondycji doradztwa zawodowego w Polsce, szczególnie w obliczu konieczności tworzenia i wdrażania przez szkoły na wszystkich poziomach kształcenia indywidualnych wewnątrzszkolnych programów doradztwa zawodowego.

\section{STAN WIEDZY}

\section{KOMPETENCJE DORADCY ZAWODOWEGO}

Za profesjonalne wsparcie uczniów w procesie planowania kariery edukacyjno-zawodowej odpowiedzialni są doradcy zawodowi - specjaliści z zakresu orientacji i poradnictwa zawodowego (Paszkowska-Rogacz, 2009). Według Bożeny Wojtasik termin „doradca zawodowy” może być definiowany w dwojaki sposób - w ujęciu węższym i szerszym. Doradca zawodu w aspekcie węższym to osoba, która poprzez interakcję z klientem udziela mu pomocy w wyborze szkoły lub zawodu. Wsparcie to ma zwykle charakter doraźny i obejmuje porady zawodowe lub/i udzielanie informacji zawodowej. W szerszym rozumieniu doradca zawodu to osoba, która podejmuje świadome i długofalowe działania w celu ukierunkowania wyboru zawodu i poznania jego specyfiki (Wojtasik, 1994). To ostatnie ujęcie wymaga od specjalisty wejścia w bliską relację z klientem celem współtowarzyszenia mu w najważniejszych momentach procesu decyzyjnego. Niebagatelną rolę odgrywają tu kwalifikacje i zasoby osobiste doradcy (Balasiewicz i in., 2014). Aktualnie do podjęcia pracy w zawodzie doradcy zawodowego jest wymagane wykształcenie wyższe I lub II stopnia (z zakresu psychologii, pedagogiki lub socjologii), przy czym w placówkach systemu oświaty (np. w szkole) konieczne jest również przygo- 
towanie pedagogiczne ${ }^{3}$. Wśród kompetencji kluczowych dla tego zawodu znajdują się: „umiejętność obsługi komputera i wykorzystania Internetu, umiejętności matematyczne, umiejętność czytania ze zrozumieniem i pisania, sprawność motoryczna, planowanie i organizowanie pracy, wywieranie wpływu/przywództwo, komunikacja ustna, współpraca w zespole, rozwiązywanie problemów" Daniela Kukli szczególnie ważne są umiejętności komunikacyjne. Wyrażają się one w takich aspektach procesu doradczego, jak: skuteczne porozumiewanie się z klientem, jasne i sugestywne prezentowanie własnego zdania, otwartość na punkt widzenia radzącego się, umiejętne argumentowanie i obronę własnego zdania, gotowość wysłuchania i brania pod uwagę podglądów i opinii innych osób, umiejętne dostosowanie się do potrzeb i możliwości klienta, aktywne korzystanie z technologii informacyjnych podczas komunikowania się, umiejętność przemawiania i prowadzenia dyskusji, spójność komunikacji werbalnej i niewerbalnej, zachęcanie do udzielania informacji zwrotnych, asertywność, umiejętne rozwiązywanie konfliktów oraz negocjowanie (Kukla, 2008; Minta, 2010). Kompetencje komunikacyjne doradcy umożliwiają „otworzenie się” na postrzeganie świata przez radzącego się. Pozwala to na zdobycie zaufania na linii doradca - klient, które jest podstawą dla tej relacji (zob. Paszkowska-Rogacz, 2009).

\section{ZADANIA DORADCY ZAWODU}

Aktualnie doradca zawodowy - zgodnie z informacjami widniejącymi w Wortalu Publicznych Służb Zatrudnienia - sygnowanym przez Ministerstwo Rozwoju, Pracy i Technologii to osoba, która ,wspomaga dzieci, młodzież i osoby dorosłe w dokonywaniu trafnych wyborów edukacyjnych i zawodowych oraz wspiera całożyciowy rozwój zawodowy. W swojej działalności wykorzystuje indywidualne i grupowe metody pracy sprzyjające określeniu potencjału osobistego, uwzględniając aktualne i prognozowane potrzeby rynku pracy i edukacji. Upowszechnia informacje dotyczące możliwości edukacyjnych i rynku pracy. Uczestniczy w doborze kandydatów na stanowiska wymagające specjalnych predyspozycji psychofizycznych oraz przy realizacji procesów restrukturyzacji zatrudnienia"5.

Doradztwo edukacyjno-zawodowe w dużej mierze dotyczy uczniów szkół podstawowych i średnich, stojących przed wyborem dalszej drogi kształcenia i zawodu. Zgodnie z przepisami ustawy z dnia 14 grudnia 2016 r. - Prawo oświa-

${ }^{3}$ Wortal Publicznych Służb Zatrudnienia prowadzony przez Ministerstwo Rozwoju, Pracy i Technologii - aktualna strona: INFOdoradca+ Informacje o zawodach (praca.gov.pl)

${ }^{4}$ Tamże.

${ }^{5}$ https://psz.praca.gov.pl/rynek-pracy/bazy-danych/infodoradca 
towe, powinno być ono realizowane na wszystkich etapach edukacyjnych, poprzez preorientację zawodową (dla przedszkoli, oddziałów przedszkolnych w szkołach podstawowych i innych formach wychowania przedszkolnego), orientację zawodową (dla klas I-VI szkół podstawowych) oraz zajęcia z zakresu doradztwa zawodowego (dla klas VII i VIII szkół podstawowych oraz określonych szkół ponadpodstawowych) ${ }^{6}$. W szkołach cykl zajęć z doradztwa zawodowego powinien być zakończony przygotowaniem przez ucznia, we współpracy z doradcą zawodowym, indywidualnego planu działania, indywidualnego portfolio kariery, czyli teczki ze zgromadzonymi materiałami i innymi efektami pracy ucznia na zajęciach (zob. Kania, 2010; Rosalska, Wawrzonek, 2012). W przypadku osób dorosłych indywidualny plan działania, zwany IPD, jest opracowywany przez doradcę zawodowego we współpracy z klientem i koncentruje się głównie na celach i działaniach zmierzających do podjęcia pracy. Niekiedy indywidualny plan działania bywa nazywany indywidualnym projektem aktywizacji lub indywidualnym planem aktywizacji (Piorunek, 2004).

Z kolei rozporządzenie z 12 lutego 2019 r. w sprawie doradztwa zawodowego, określa treści programowe dla poszczególnych etapów edukacyjnych i typów szkół (w załącznikach do rozporządzenia) ${ }^{7}$. Wskazuje jednocześnie na konieczność corocznego opracowywania przez szkoły indywidualnego programu WSDZ ${ }^{8}$, obejmującego wszelkie działania z podziałem na poszczególne oddziały oraz określającego tematykę oraz osoby odpowiedzialne za ich realizację. Dodatkowo w programie powinny się znaleźć metody, formy i terminy wykonania poszczególnych aktywności, z uwzględnieniem udziału wszystkich członków szkolnej społeczności, w tym również rodziców (por. Musialska, 2010).

Z powyższego wynika, że pierwszy filar zintegrowanego modelu poradnictwa zawodowego ma stanowić profesjonalna kadra doradców zawodowych w szkołach (Siarkiewicz, 2010). Rolę wspierającą mają pełnić podmioty zewnętrzne, w tym poradnie psychologiczno-pedagogiczne.

Zgodnie z Rozporządzeniem MEN z 1 lutego 2013 roku w sprawie szczegółowych zasad działania publicznych poradni psychologiczno-pedagogicznych, do obowiązków doradców zawodowych należą:

${ }^{6}$ Ustawa z dnia 14 grudnia 2016 r. Prawo oświatowe (Dz. U. z 2020 r. poz. 910 i 1378 oraz z 2021 r. poz. 4).

7 Treści programowe zostały opracowywane przez ekspertów z zakresu poradnictwa zawodowego, jak również przedstawicieli szkół i placówek, organów prowadzących, pracodawców i związków zawodowych, instytucji rynku pracy w projekcie „Efektywne doradztwo edukacyjno-zawodowe dla dzieci, młodzieży i dorosłych" zrealizowanym przez ORE w Warszawie.

${ }^{8}$ Rozporządzenie Ministra Edukacji Narodowej z dnia 12 lutego 2019 r. w sprawie doradztwa zawodowego (Dz. U. poz. $325, \S 4$ ). 
„1) systematyczne diagnozowanie zapotrzebowania uczniów na informacje edukacyjne i zawodowe oraz pomoc w planowaniu kształcenia i kariery zawodowej;

2) gromadzenie, aktualizacja i udostępnianie informacji edukacyjnych i zawodowych właściwych dla danego poziomu kształcenia;

3) prowadzenie zajęć związanych $\mathrm{z}$ wyborem kierunku kształcenia i zawodu z uwzględnieniem rozpoznanych mocnych stron, predyspozycji, zainteresowań i uzdolnień uczniów;

4) koordynowanie działalności informacyjno-doradczej prowadzonej przez szkołę i placówkę;

5) współpraca $z$ innymi nauczycielami w tworzeniu i zapewnieniu ciągłości działań w zakresie zajęć związanych z wyborem kierunku kształcenia i zawodu;

6) wspieranie nauczycieli, wychowawców grup wychowawczych i innych specjalistów w udzielaniu pomocy psychologiczno-pedagogicznej"”.

W kontekście powyższego dokumentu rola specjalistów z poradni psychologiczno-pedagogicznych sprowadza się w dużej mierze do rozwiązywania indywidualnych problemów uczniów związanych z wyborem szkoły i zawodu, ze szczególnym uwzględnieniem młodzieży ze specjalnymi potrzebami edukacyjnymi. W większym stopniu jest też realizowana współpraca ze szkołami, nastawiona na metodyczne i merytoryczne wsparcie uczniów i nauczycieli ${ }^{10}$ (zob. Siarkiewicz, 2010).

\section{WYBÓR ZAWODU JAKO PROCES}

Obecnie proces wyboru zawodu nie jest już postrzegany jako jednorazowy akt, lecz zespół działań o charakterze długofalowym, rozpoczynający się we wczesnym dzieciństwie i trwający przez całe życie człowieka (Wojtasik, 2010; Wołk, 2006). Wybór zawodu jest więc doświadczeniem, które jednostka może powtórzyć, szukając ważnych dla siebie rozwiązań na różnych etapach życiowych. Wybór szkoły czy zawodu ma więc charakter dynamiczny, pozostając w relacji z innymi obszarami funkcjonowania jednostki (por. Musialska, 2010; Olszewska-Gniadek, 2020).

W tym miejscu trzeba podkreślić, że o ile dawniej doradcy wręcz wyręczali osoby radzące się (niekiedy decydując za nie), o tyle obecnie poradnictwo zawodowe zmierza w kierunku aktywizowania jednostki do poszukania informacji, poznawania siebie, autorefleksji, podejmowania samodzielnych decyzji. Doradca zawodu

${ }^{9}$ Rozporządzenie MEN z 1 lutego 2013 roku w sprawie szczegółowych zasad działania publicznych poradni psychologiczno-pedagogicznych w tym poradni specjalistycznych (Dz. U. 2013 poz. 199 z późn. zm.).

${ }^{10}$ Rozporządzenie Ministra Edukacji Narodowej z dnia 12 lutego 2019 roku w sprawie doradztwa zawodowego (Dz. U. poz. 325, §5). 
zajmuje się wiec już nie tylko osobami biernymi, bezradnymi, pasywnymi, ale także przedsiębiorczymi, aktywnymi i zaradnymi (Kargulowa, 2005; Wojtasik, 1993).

Niemniej kluczowe w procesie doradczym jest doprowadzenie do spotkania i nawiązania dobrego kontaktu $\mathrm{z}$ klientem. Specjalista przyjmuje w tej relacji określoną postawę, która według Bożeny Wojtasik może przybrać postać jednego z pięciu modeli (zob. Wojtasik, 1993). Pierwszym z nich jest ekspert, którego głównym zadaniem jest udzielanie instrukcji, poleceń i wskazówek. Drugi to doradca-konsultant, specjalizujący się w udzielaniu porad. Trzeci model to doradca-informator, który zaznajamia petenta z informacjami na temat ofert pracy, zawodów, przedstawia możliwości odbycia szkoleń i stara się ich zaktywizować. Czwartym modelem jest model spolegliwego opiekuna. Tego typu doradca musi wykazać się wiedzą psychologiczną, aby wesprzeć i ukierunkować klienta w taki sposób, żeby ten uwierzył we własne możliwości, a w konsekwencji sam poradził sobie $\mathrm{z}$ wyborem ścieżki zawodowej. Piąty - i zarazem ostatni - model doradcy zawodowego to leseferysta. On też „nie ocenia, nie krytykuje, nie poucza, [...] nie udziela żadnych rad. Natomiast towarzyszy klientowi” (Bartoszek, 2008, s. 65).

To z kolei wymaga od doradcy posiadania profesjonalnych kompetencji zawodowych i zestawu odpowiednich cech osobowych. Jak podaje Słownik Pedagogiki Pracy, , aby doradca zawodu mógł dobrze realizować stawiane przed nim zadania, powinien nie tylko dysponować wiedzą o zawodach, posiadać znajomość psychologii i pedagogiki, mieć praktykę pedagogiczną, ale również posiadać życzliwość dla młodzieży i gotowość pomocy" (Koczniewska-Zagórska i in., 1986, s. 54-55). Potwierdzają to wyniki badań przeprowadzonych przez Bożenę Wojtasik, w których ankietowana młodzież w sposób szczególny wyróżniła postawy doradców życzliwych, miłych i sympatycznych, potrafiących rozumieć drugiego człowieka oraz prawdziwie zaangażowanych w ich sprawy (Wojtasik, 2011, s. 66; 1993; 2012).

\section{OBSZARY DZIAŁANIA DORADCY}

Podstawowymi obszarami działania doradcy zawodowego są „orientacja i poradnictwo zawodowe”. Większość autorów definiuje „orientację zawodową” w szerokim znaczeniu i określa ją jako celową, systematyczną i długotrwałą działalność prowadzącą do trafnego wyboru zawodu (por. Paszkowska-Rogacz, 2009). Tutaj też można wyróżnić wstępną część tego procesu zwaną preorientacją zawodową, nastawioną na zapoznanie dzieci $w$ wieku przedszkolnym i wczesnoszkolnym $z$ wybranymi zawodami oraz pobudzanie i rozwijanie ich zainteresowań i uzdolnieńn ${ }^{11}$.

${ }^{11}$ Ustawa z dnia 14 grudnia 2016 r. - Prawo oświatowe (Dz. U. z 2020 r. poz. 910 i 1378 oraz z 2021 r. poz. 4). 
Utożsamia się tę działalność z procesem wychowawczym - wychowaniem do wyboru zawodu. Natomiast „poradnictwo zawodowe” jest w polskim piśmiennictwie rozumiane najczęściej w sensie węższym - jako udzielanie pomocy w wyborze zawodu - głównie przez poradę. Podkreśla się przy tym ważność relacji, w jaką wchodzi doradca $\mathrm{z}$ radzącym się (Wojtasik, 2011; 2012). Jak celnie zauważa Ewa Wysocka, kontakt z klientem, którego celem jest diagnoza, opiera się w dużej mierze na interakcji, a tu zdecydowanie mniejsze znaczenie ma treść w stosunku do warunków i jakości jej przebiegu. Istotne stają się tym samym dwa kluczowe elementy spotkania: kontakt werbalny i kontakt niewerbalny (Wysocka, 2013).

Doradca zawodowy w poradni psychologiczno-pedagogicznej udziela najczęściej pomocy w wyborze zawodu i kierunku kształcenia młodzieży kończącej szkołę podstawową i średnią. Uwzględnia przy tym możliwości psychofizyczne i sytuację życiową. Współpracuje z rodzicami i nauczycielami w procesie orientacji zawodowej uczniów. Wykorzystuje swoją wiedzę o zawodach, rynku pracy oraz technicznych środkach przekazywania informacji zawodowej. Doradcy zawodu pracujący w poradni prowadzą również diagnostyczne badania zainteresowań i predyspozycji zawodowych uczniów, najczęściej tych z przeciwwskazaniami zdrowotnymi do wyboru zawodu. Zajmują się także grupowym poradnictwem, prowadząc prelekcje oraz warsztaty wyboru drogi edukacyjno-zawodowej w szkołach. Przekazują także informacje o rynku pracy, zawodach, szkołach, zasadach rekrutacji uczniom, nauczycielom i rodzicom (Paszkowska-Rogacz, 2002; 2009).

Podjęte działania z zakresu doradztwa zawodowego realizowane we współpracy ze szkołami mają ułatwić młodym ludziom poznanie swoich predyspozycji zawodowych, a co za tym idzie adekwatne do ich możliwości planowanie kariery edukacyjno-zawodowej i wejście na rynek pracy (Rosalska, Wawrzonek, 2012). Zdaniem Alicji Łukaszewicz „proces przygotowywania młodzieży do podjęcia decyzji edukacyjnych i zawodowych ma ogromne znaczenie społeczne i można określić go jako działalność prewencyjną - chroniącą przed nietrafnymi wyborami, zapobiegającą utracie motywacji do nauki i pracy, oszczędzającą czas i pieniądze. Instytucje, które wkraczają ze swoją pomocą później (OHP, urzędy pracy), mogą tylko próbować złagodzić skutki niewłaściwych decyzji, ale nie są w stanie odwrócić ich negatywnych efektów" (Łukaszewicz, 2008, s. 46).

\section{DORADZTWO INDYWIDUALNE I GRUPOWE}

Doradztwo edukacyjno-zawodowe jest realizowane $\mathrm{w}$ formie indywidualnej i grupowej. W przypadku kontaktu z klientem indywidualnym najczęściej praktykuje 
się poradę zawodową. Składa się ona z kilku etapów, zgodnych z koncepcją Bożeny Wojtasik (1994):

1. Etap 1. Przygotowanie się doradcy do przeprowadzenia rozmowy. Zanim doradca spotka się z klientem, sprawdza, czy miał on już kontakt z poradnią i czy jest dostępna stosowna dokumentacja. Jeśli tak, dokonuje wstępnych ustaleń, próbuje wyznaczyć główne cele i przebieg rozmowy.

2. Etap 2. Pierwszy kontakt. Polega on na nawiązaniu pozytywnego kontaktu z klientem. Ważne jest pierwsze wrażenie i warunki spotkania (wygląd doradcy, ustawienie biurka, krzeseł itp.). Rozmowa z radzącym się najczęściej jest prowadzona niedyrektywnie, przenosząc aktywność i sposób prezentacji problemu na klienta.

3. Etap 3. Ustalenie, kto ma problem i na czym on polega. Jeśli klient stwierdzi, że przyszedł tu nie z własnej woli, lecz za namową innych osób, jest to sygnał, że nie uznaje problemu za swój. Zadaniem doradcy jest sprowadzenie rozmowy na takie tory, żeby radzący wyraził niczym nie przymuszoną chęć wejścia $\mathrm{w}$ relację ze specjalistą $\mathrm{z}$ konkretnego powodu.

4. Etap 4. Zawarcie kontraktu między doradca a radzącym się. Ma on na celu ustalenie zasad współpracy między doradcą a radzącym się poprzez wytyczenie celów, do których wspólnie dążą, określenie granic odpowiedzialności za przebieg procesu i uzyskane wyniki. Zwykle proces doradczy jest rozłożony w czasie i obejmuje kilka wizyt, co powinno zostać podkreślone już podczas pierwszego spotkania. Warto również uświadomić klientowi, że oczekuje się od niego postawy aktywnej, np. w zakresie zdobywania wiedzy o sobie samym, o zawodach. Aby radzący poczuł się bezpiecznie w nowej sytuacji, powinien także zostać poinformowany o zasadzie poufności całego procesu.

5. Etap 5. Budowanie relacji doradca - radzacy się. Na tym etapie można zająć się pogłębianiem relacji. Ważna jest jakość interakcji doradca-radzący się, poziom wzajemnego zaufania. Klient może na tym etapie zdecydować, czy chce kontynuować relację, czy ją przerwać.

6. Etap 6. Zbieranie faktów oraz badanie pedagogiczne i psychologiczne. Doradca poznaje sytuację rodzinną i szkolną ucznia, jego zainteresowania, uzdolnienia, mocne i słabe strony. Radzący się dokonuje samopoznania i samooceny. Na ogół doradca proponuje na tym etapie badanie predyspozycji zawodowych. Po przeprowadzeniu rozmów i zastosowaniu wybranych testów psychologicznych i pedagogicznych następuje omówienie z klientem wyników badań i wspólne wypracowanie sposobów dalszego działania.

7. Etap 7. Aktywizowanie radzacego się do zbierania informacji o zawodach $i$ szkołach. Osobą najbardziej aktywną w procesie wyboru zawodu jest 
klient. Doradca nie wyręcza go w poszukiwaniach, ale mobilizuje do tego, aby samodzielnie poszukiwał informacji, a następnie analizował je zgodnie z własnym systemem wartości. Wskazuje mu źródła, z których może czerpać wiedzę o własnych zasobach, kierunkach i ścieżkach kształcenia, zawodach, rynku pracy; niczego jednak nie ocenia, nie narzuca.

8. Etap 8. Konsultacja z rodzicami. Jeżeli osobą radzącą się jest uczeń, niezbędna jest zgoda rodziców na poradę oraz rozmowa na temat zainteresowań dziecka, jego możliwości itp. Może nastąpić przedstawienie przez rodziców własnych propozycji zawodu wybranego dla dziecka, może rozwinąć się dyskusja i uzgodnienie stanowisk. Brane są też pod uwagę możliwości finansowe rodziny, różnice w interesach itp.

9. Etap 9. Dopasowanie siebie do zawodu. W tym etapie trzeba rozważyć, czy czynniki wewnętrzne (m.in. zainteresowania, wartości, możliwości) oraz zewnętrzne (m.in. środowisko rodzinne, rówieśnicze, szkole) będą sprzyjały wykonywaniu wybranego wspólnie zawodu czy grupy zawodów. Następuje tutaj wspólne planowanie, dyskusja nad rozwiązaniami. Etap ten kończy się wyborem zawodu/dalszego kierunku kształcenia/szkoły. Zwykle towarzyszy temu poszukiwanie szczegółowych informacji na temat przebiegu procesu rekrutacji.

10. Etap 10. Zakończenie. Na zakończenie następuje zwykle podsumowanie wspólnych osiągnięć, ocena tego, co zostało wykonane. Jeżeli nie osiągnięto zamierzonych celów, należy zastanowić się nad przyczynami. Można poprosić osobę radzącą się o podsumowanie. Można też zachęcić klienta do dalszych kontaktów.

W praktyce poradnianej zwykle już pierwsze spotkanie obejmuje cztery kolejne stadia procesu pomagania. Dziesięć etapów przebiega zazwyczaj w ciągu dwóch, trzech spotkań doradcy z osobą radzącą się ${ }^{12}$.

W indywidualnym poradnictwie zawodowym nie muszą jednak występować wszystkie wymienione etapy. Nie zawsze jest to konieczne, a niekiedy nie jest to po prostu możliwe. Każdy doradca uwzględnia jednak trzy główne fazy: otwarcie, przepracowanie problemu i zakończenie (Wojtasik, 1991).

Ważnym aspektem pracy doradcy zawodowego jest poradnictwo grupowe. Jego celem jest merytoryczne i metodyczne wsparcie uczniów, rodziców i nauczycieli w realizacji wewnątrzszkolnego systemu doradztwa zawodowego (Łukaszewicz, 2008; Paszkowska-Rogacz, 2009).

${ }^{12}$ Na podstawie wywiadów nieskategoryzowanych przeprowadzonych w 2019 roku z 7 doradcami zawodowymi zatrudnionymi w krakowskich poradniach psychologiczno-pedagogicznych. 
Szczególnie bogata jest oferta skierowana do uczniów klas VII i VIII szkół podstawowych. Składają się na nią: prelekcje oraz warsztaty zawodoznawcze ${ }^{13}$.

Prelekcje zawodoznawcze organizowane są na terenie szkół podstawowych, osobno dla każdej klasy. Mają one na celu podnieść poziom refleksyjności uczniów nad własną przyszłością oraz w przystępny sposób przekazać młodzieży m.in.:

- podstawowe wiadomości na temat strategii wyboru szkoły i zawodu, czynników istotnych w planowaniu kariery edukacyjno-zawodowej;

- podstawową wiedzę o zawodach, ich specyfice i wymaganiach;

- wiedzę o aktualnej sytuacji na rynku pracy, o zawodach deficytowych i nadwyżkowych;

- informacje na temat ścieżek kształcenia i rodzajów szkół średnich, zasadach rekrutacji;

- informacje na temat sposobów uzyskania pomocy w zakresie wyboru szkoły, zawodu ${ }^{14}$.

Prelekcja trwa zwykle 45 minut i ma formę wykładu wzbogaconego prezentacją multimedialną. Większość spotkań kończy się konwersacją z uczniami na temat przedstawionych treści.

Inną formą zajęć skierowaną do młodzieży klas ósmych szkoły podstawowej są warsztaty zawodoznawcze ${ }^{15}$. Maja one na celu przybliżyć uczniom świat zawodów, wymagań stawianych przez nie, przeciwwskazań zdrowotnych, pomóc umiejscowić siebie w wybranych rolach zawodowych, pomóc sprecyzować konkretny plan drogi do zawodu, a co za tym idzie dopomóc w podjęciu optymalnej decyzji edukacyjno-zawodowej (por. Paszkowska-Rogacz, 2009; Olszewska-Gniadek, 2020).

Tego typu zajęcia obywają się najczęściej osobno dla każdej klasy i trwają od 2 do 3 godzin. Udział w nich jest dobrowolny. Spotkanie prowadzi doradca zawodowy z pomocą wychowawcy bądź pedagoga szkolnego.

Warsztat składa się zazwyczaj z kilku modułów, obejmujących takie etapy, jak: wprowadzenie i prezentacja, poznanie siebie (odkrywanie mocnych i słabych stron), poznawanie zawodów i ścieżek kształcenia, zawodowa przymiarka, indywidualny plan działania, zakończenie (por. Paszkowska-Rogacz, 2002).

Warto dodać, że działaniami z zakresu orientacji i poradnictwa zawodowego przez pracowników poradni zostają również objęci rodzice uczniów. Oni też

13 Tamże.

14 Tamże.

15 Jak wynika z treści wywiadów przeprowadzonych z doradcami zawodowymi z krakowskich poradni psychologiczno-pedagogicznych, na terenie podopiecznych szkół podstawowych są prowadzone warsztaty zawodoznawcze dla siódmo i ósmoklasistów, m.in. „I co dalej ósmoklasisto?” (PPP nr 4 w Krakowie), „Wybieram zawód czy szkołę średnią?” (PPP nr 2), „Pierwszy krok w kierunku kariery zawodowej” (PPP nr 1)”. 
występują tutaj w podwójnej roli: jako osoby radzące się i jako doradcy. Mając na uwadze duży wpływ, jaki wywierają rodzice na decyzje zawodowe swoich dzieci, pracownicy poradni organizują dla nich zajęcia. Dawniej były to głównie odczyty i wykłady. Teraz są to również warsztaty dla rodziców ${ }^{16}$.

Zajęcia te są prowadzone przez doradców poradni na terenie szkoły. Zwykle trwają ok. dwóch godzin i mają charakter dobrowolny. Oprócz krótkiego wykładu wprowadza się ćwiczenia praktyczne, które dotyczą mocnych stron ich dziecka, a także własnych doświadczeń w planowaniu kariery zawodowej.

Większość opracowań na temat wsparcia ucznia w procesie wyboru zawodu dotyczy szkoły podstawowej. W ostatnich latach pojawiły się również publikacje skierowane do uczniów szkół średnich, których współautorami są również pracownicy poradni ${ }^{17}$. Oni też wykorzystują te materiały w swojej praktyce zawodowej.

Najbardziej popularną formą pracy z młodzieżą szkół średnich, realizowaną na terenie podopiecznych placówek, są prelekcje obejmujące następujące zagadnienia:

- czynniki wyboru zawodu i szkoły;

- poznanie siebie;

- poznanie zawodów i specjalności: humanistycznych, matematyczno-fizycznych, przyrodniczo-medycznych, ekonomicznych, prawnych, organizacji i zarządzania, technicznych, opiekuńczo-wychowawczych, sportowo-turystycznych, kultury i sztuki;

- kierunki i specjalności szkół policealnych;

- kierunki i specjalności wyższych uczelni;

- poszukiwane zawody;

- jak szukać pracy itp.

Propozycją skierowaną do uczniów liceów ogólnokształcących są warsztaty zawodoznawcze ${ }^{18}$. Mają one na celu ukształtowanie postaw aktywnych i zapoznanie uczniów ze sposobami i technikami efektywnego poszukiwania pracy. Warsztat jest przeznaczony dla uczniów ostatnich klas liceum ogólnokształcącego, osobno

${ }^{16}$ Jak wynika $\mathrm{z}$ treści wywiadów przeprowadzonych $\mathrm{z}$ doradcami zawodowymi w krakowskich poradniach psychologiczno-pedagogicznych, na terenie podopiecznych szkół podstawowych są realizowane warsztaty zawodoznawcze dla rodziców uczniów klas VIII, m.in. „Moje dziecko wybiera zawód” (PPP nr 4 w Krakowie), „Jak pomóc dziecku zaplanować karierę edukacyjno-zawodową?" (PPP nr 2 w Krakowie).

${ }_{17}$ Przykładem może być Program Modułowy dla szkół ponadgimnazjalnych opracowany przez Krakowską Szkołę Doradztwa Zawodowego, dostępny w publikacji: M. Piekarski, E. Zadęcka, Co dalej po dyplomie czyli rozwój w kierunku kompetencji. Modułowy program poradnictwa zawodowego dla uczniów szkół ponadgimnazjalnych prowadzonych przez Gminę Miejską Kraków, Kraków 2015.

${ }_{18}$ Jak wynika $\mathrm{z}$ treści wywiadów przeprowadzonych $\mathrm{z}$ doradcami zawodowymi w krakowskich poradniach psychologiczno-pedagogicznych, na terenie podopiecznych szkół średnich są realizowane warsztaty zawodoznawcze dla uczniów klas III i IV liceum, m.in. „I co dalej licealisto?” (PPP nr 4 w Krakowie), „Moje atuty moją siłą” (PPP nr 2 w Krakowie). 
dla każdej klasy. Najprostszy warsztat składa się z trzech bloków, a każdy z nich trwa ok. godziny: blok 1: poznanie samego siebie, blok 2: drogi poszukiwania pracy, blok 3: autoprezentacja - kontakt z pracodawcą oraz podsumowania. Wśród proponowanych ćwiczeń znajdują się m.in. pisanie ofert, przygotowanie się do rozmowy kwalifikacyjnej, pisanie podań, gry symulacyjne - rozmowy z pracodawcą itp. (por. Paszkowska-Rogacz, 2002; Paszkowska-Rogacz, Tarkowska, 2004).

\section{NARZĘDZIA W PRACY DORADCY}

Na terenie poradni do dyspozycji doradców zawodu są różnorodne testy pedagogiczno-psychologiczne, kwestionariusze wywiadów z uczniem lub rodzicami (Frydrychowicz i in., 2004).

Ich dobór zależy od indywidualnych możliwości i upodobań doradcy oraz od potrzeb i oczekiwań klienta (Bluszcz, 2017). Najczęściej stosowane w praktyce doradcy zawodowego w poradni są m.in.: Kwestionariusz Zainteresowań Zawodowych, Inwentarz Zainteresowań, Kwestionariusz Inteligencji Wielorakiej H. Gardnera, Kwestionariusz Predyspozycji Zawodowych Klimowa, Moja kariera Scheina. Wielowymiarowy Kwestionariusz Preferencji WKP, Profil Zainteresowań Zawodowych (PZZ). Dużym zainteresowaniem wśród doradców cieszy się również test: Skala Zdolności Specjalnych (SZS). Dla osób z niepełnosprawnością intelektualną również dostępny jest test do diagnozy zawodoznawczej np.: Profil Zainteresowań Zawodowych dla uczniów o obniżonych możliwościach intelektualnych (PZZ INTE) ${ }^{19}$.

Przez ostatnie lata obserwowano na rynku oświaty wyraźny niedobór materiałów wspomagających pracę specjalistów z zakresu doradztwa zawodowego w szkołach i w poradniach. W odpowiedzi na to zrealizowano wiele projektów (m.in. ORE, Krakowskiej Szkoły Doradztwa Zawodowego) o różnym zasięgu, których efektem są publikacje zawierające scenariusze lekcji zawodoznawczych oraz narzędzia do diagnozy zasobów osobistych uczniów ${ }^{20}$ (por. Kania, 2010).

Dostępne są również informacje na temat rekomendowanych przez władze oświatowe narzędzi do badań zawodoznawczych: Diaprezmus; Labirynt zawodów; MŁOKOZZ; Vademecum Talentu; Wybieram zawód; Talent game ${ }^{21}$.

${ }^{19}$ Na podstawie treści wywiadów przeprowadzonych z doradcami zawodowymi w krakowskich poradniach psychologiczno-pedagogicznych.

${ }^{20}$ Patrz m.in. na materiały dla doradców zawodowych szkół podstawowych, gimnazjalnych i średnich opracowane przez Krakowską Szkołę Doradztwa Zawodowego (pzo.edu.pl).

${ }^{21} \mathrm{https}$ //doradztwo.ore.edu.pl/narzedzia-diagnostyczne-dla-doradcow-zawodowych/ [dostęp: 1.02.2021]. 
W poradnictwie zawodowym próbuje się również wykorzystać nowoczesne technologie. Większość testów zawodoznawczych jest już dostępna w wersji komputerowej, powstają też liczne platformy e-learningowe zawierające materiały wspierające proces planowania kariery edukacyjno-zawodowej oraz umożliwiające zdalny kontakt ze specjalistami w tym zakresie. Są one zwykle częścią większych programów (np. finansowanych ze środków Unii Europejskiej), gdzie obok form indywidualnych i grupowych w kontakcie bezpośrednim realizowana jest również współpraca w kontakcie online. Jest to szczególnie przydatne aktualnie, w warunkach pandemii, kiedy szkoły nie pracują w normalnym trybie, lecz na odległość.

\section{WNIOSKI I PODSUMOWANIE}

Z powyższych rozważań wynika, że poradnia psychologiczno-pedagogiczna pełni istotną rolę w procesie wsparcia wyborów zawodowych młodzieży. Zatrudnieni tam specjaliści świadczą usługi dla uczniów szkół podstawowych i średnich, ich rodziców oraz nauczycieli. Od współczesnego doradcy oczekuje się wysokich kwalifikacji formalnych i kompetencji, a także szczególnych cech osobowych, takich jak: otwartość, życzliwość, empatia, komunikatywność, cierpliwość (Kukla, 2008; Wojtasik, 2010). Ważna jest również rzetelna i aktualna wiedza o zawodach, ścieżkach i kierunkach kształcenia, warunkach rekrutacji, sytuacji na rynku pracy. Pożądaną cechą jest też elastyczność - umiejętność przyjmowania, w zależności od sytuacji, roli: eksperta, informatora, spolegliwego opiekuna czy leseferysty (Wojtasik, 1993; Bartoszek, 2008).

Ponadto doradca zawodowy w poradni stosuje dwie główne formy pracy: indywidualną i zbiorową (Wojtasik, 1991; 2012). Ta pierwsza opiera się na diagnozie zawodoznawczej (często poszerzonej o badanie psychologiczne potencjału intelektualnego), druga zaś realizowana jest w podopiecznych szkołach poprzez prelekcje i warsztaty adresowane do uczniów, rodziców i nauczycieli. Warsztat doradcy zawodu jest tworzony zgodnie z przepisami prawa oświatowego, stosownie do potrzeb i oczekiwań różnych grup klientów. Szczególną pomocą otoczeni są uczniowie z problemami zdrowotnymi i orzeczoną niepełnosprawnością. Dla nich też dostępne są specjalistyczne metody i narzędzia do diagnozowania ich zasobów osobistych i predyspozycji zawodowych (Bluszcz, 2017).

W obliczu szybkich zmian, jakie dokonują się w życiu społeczno-politycznym naszego kraju, pomoc świadczona ze strony doradców zawodowych wydaje się konieczna na każdym etapie życia człowieka (Musialska, 2010). Niezbędne jest więc stworzenie takiego systemu doradztwa zawodowego, który dostarczy uczniom wiedzy na temat możliwości zdobycia zawodów oferowanych przez szkoły oraz 
wymagań, jakie stawiają one kandydatom, a także umożliwi skuteczne odkrywanie i rozwijanie własnych uzdolnień, posiadanych umiejętności, kwalifikacji i zainteresowań (w aspekcie życzeniowym i rzeczywistym). Ponadto tworzony system doradztwa winien zapewnić poznanie procesu decyzyjnego oraz konsekwencji dokonywanych wyborów (Bluszcz, 2017). Wreszcie powinien stworzyć możliwość kształcenia umiejętności radzenia sobie ze zmianami poprzez rozwijanie umiejętności adaptacyjnych oraz umiejętności wychodzenia naprzeciw nowym sytuacjom i nowym wyzwaniom (Wojtasik, 2011; Łączek, 2019).

Współczesne doradztwo edukacyjno-zawodowe nie powinno być zamknięte w „kapsule przeszłości” (Jaskulska, 2015, s. 15-16). Nie mamy bowiem pojęcia, jak będzie wyglądał świat za kilka czy kilkanaście lat. Istnieją oczywiście pewne prognozy specjalistów, ale są one obarczone dużym ryzykiem błędu (por. Musialska, 2010; Rosalska, Wawrzonek, 2012).

Dzisiejsze poradnictwo znacznie wykracza więc poza interpretację wyników otrzymanych w testach zainteresowań. Doradca występuje coraz częściej w roli towarzysza, eksperta od rozumienia procesu i stosowania odpowiednich narzędzi, a nie od rozwiązywania problemu za osobę (Wojtasik, 2011). Wspiera w poszukiwaniu tego, co dla jednostki jest ważne i wartościowe. Daje rady, motywuje do działania, ale niczego nie narzuca. Stwarza warunki do rozwoju kompetencji społecznych, niezbędnych do radzenia sobie w sytuacjach trudnych i samodzielnego poszukiwania informacji. Poradnictwo staje się więc wytyczaniem celów i poszukiwaniem rozwiązań na różnych etapach życia. Wszystko zaś powinno odbywać się w atmosferze dobrowolności i wzajemnego szacunku. Wartością nadrzędną jest dobro jednostki i temu winien służyć cały proces wsparcia w życiowych wyborach (zob. Chirkowska-Smolak i in., 2011; Bluszcz, 2017; Łączek, 2019).

\section{BIBLIOGRAFIA}

Balasiewicz, A., Błaut, R., Chojnacki, W. (2014). Słownik pedagogiki pracy i organizacji. Warszawa: Aspra.

Bartoszek, A. (2008). Rola i zadania doradcy zawodowego w urzędzie pracy - teoria i praktyka. W: E. Ziarkiewicz. B. Wojtasik (red.). Być doradcą! Doświadczenia i refleksje (s. 64-70). Wrocław: Wyd. Naukowe Dolnośląskiej Szkoły Wyższej.

Bluszcz, J. (2017). Doradca zawodowy na drodze do profesjonalizmu: oczekiwania a rzeczywistość. Warszawa: Wyd. Akademii Pedagogiki Specjalnej im. M. Grzegorzewskiej. Chirkowska-Smolak, T., Hauziński, A., Łaciak, M. (2011). Drogi kariery. Jak wspomagać rozwój zawodowy dzieci i młodzieży. Warszawa: Scholar. 
Frydrychowicz, A., Koźniewska, E., Sobolewska, M., Zwierzyńska, E. (2004). Testy psychologiczne i pedagogiczne w poradnictwie. Przewodnik metodyczny. Warszawa: Centrum Metodyczne Pomocy Psychologiczno-Pedagogicznej.

Jaskulska, A. (2015). Poradnictwo edukacyjno-zawodowe w poradni psychologiczno-pedagogicznej. Pomaganie z pasja. Warszawa: KOWEZiU.

Kania, I. (2010). Jak towarzyszyć uczniom w rozwoju społeczno-zawodowym? Gry szkoleniowe i scenariusze zajęć do pracy z młodzieżą. Warszawa: Difin.

Kargulowa, A. (2004). O teorii i praktyce poradnictwa. Warszawa: PWN.

Kargulowa, A. (2005). O teorii i praktyce poradnictwa. Warszawa: PWN.

Koczniewska-Zagórska, L., Nowacki, T.W., Wiatrowski, Z. (1986). Termin: Doradca zawodu (red.). Słownik pedagogiki pracy (s. 54-55). Wrocław: Zakład Narodowy im. Ossolińskich.

Kukla, D. (2008). Kompetencje komunikacyjne jako atrybut doradcy zawodowego. W: D. Kukla (red.). Komunikacja w doradztwie zawodowym (s. 49-62). Radom: ITE - PIB. Łączek, T. (2019). Determinanty sukcesu życiowego młodzieży. Toruń: Adam Marszałek. Łukaszewicz, A. (2008). Wewnątrzszkolny system doradztwa, czyli przygotowanie młodzieży do wejścia na rynek pracy w warunkach polskich. W: M. Kotarba (red.). ABC poradnictwa zawodowego w szkole (s. 25-47). Warszawa: KOWEZiU.

Minta, J. (2010). Rozmowa doradcza we współczesnym poradnictwie kariery. W: J. Bielecki. A. Dziedzic, M. Łuczak (red.). Metody i narzędzia stosowane w Polsce przez doradców zawodowych w sektorze edukacji. Materiały poseminaryjne (s. 25-33). Warszawa: Krajowy Ośrodek Wspierania Edukacji Zawodowej i Ustawicznej.

Musialska, K. (2010). Aspiracje życiowe młodzieży stojącej u progu dorosłości. Kraków: Impuls.

Olszewska-Gniadek, J. (2015). Modele kompetencji współczesnego pracownika. W: M. Piekarski. E. Zadęcka (red.). Co dalej po dyplomie czyli rozwój w kierunku kompetencji. Modułowy program poradnictwa zawodowego dla uczniów szkót ponadgimnazjalnych prowadzonych przez Gminę Miejska Kraków (s. 235-288). Kraków: Krakowska Szkoła Doradztwa Zawodowego.

Olszewska-Gniadek, J. (2020). Uwarunkowania wyborów edukacyjno-zawodowych 15-16- latków - determinanty sukcesu. W: T. Łączek (red.). Sukces życiowy w społeczeństwie konsumpcyjnym (s. 125-142). Warszawa: Difin.

Paszkowska-Rogacz, A. (2002). Warsztat pracy europejskiego doradcy kariery zawodowej. Warszawa: Krajowy Ośrodek Wspierania Edukacji Zawodowej i Ustawicznej.

Paszkowska-Rogacz, A. (2003). Psychologiczne podstawy wyboru zawodu. Przegląd koncepcji teoretycznych. Warszawa: Krajowy Ośrodek Wspierania Edukacji Zawodowej i Ustawicznej.

Paszkowska-Rogacz, A., Tarkowska, M. (2004). Metody pracy z grupa w poradnictwie zawodowym. Warszawa: Krajowy Ośrodek Wspierania Edukacji Zawodowej i Ustawicznej. 
Paszkowska-Rogacz, A. (2009). Doradztwo zawodowe. Wybrane metody badań. Warszawa: Difin.

Piorunek, M. (2004). Projektowanie przyszłości edukacyjno-zawodowej w okresie adolescencji. Poznań: Wyd. Naukowe UAM.

Rosalska, M., Wawrzonek, A. (2012). Między szkoła a rynkiem pracy. Doradztwo zawodowe $w$ szkołach zawodowych. Warszawa: Difin.

Rozporządzenie Ministra Edukacji Narodowej z dnia 1 lutego 2013 roku w sprawie szczegółowych zasad działania publicznych poradni psychologiczno-pedagogicznych w tym poradni specjalistycznych (Dz. U. 2013 poz. 199 z późn. zm.).

Rozporządzenie Ministra Edukacji Narodowej z dnia 12 lutego 2019 roku w sprawie doradztwa zawodowego (Dz. U. poz. 325).

Siarkiewicz, E. (2010). Przesłonięte obszary poradnictwa. Realia - iluzje - ambiwalencje. Zielona Góra: Oficyna Wydawnicza Uniwersytetu Zielonogórskiego.

Ustawa z dnia 14 grudnia 2016 r. Prawo oświatowe (Dz. U. z 2020 r. poz. 910 i 1378 oraz z 2021 r. poz. 4).

Ustawa z dnia 7 września z 1991 r. o systemie oświaty - Dz. U. z 2020 r. poz. 1327 oraz z 2021 r. poz. 4 i 1237.

Wojtasik, B. (1993). Wybór doradcy zawodu przez młodzież, rodziców i nauczycieli. Wrocław: Wrocławska Oficyna Wydawnicza.

Wojtasik, B. (1994). Doradca zawodu: studium teoretyczne z zakresu poradoznawstwa. Wrocław: Wyd. Uniwersytetu Wrocławskiego.

Wojtasik, B. (2010). Proces zmian w poradnictwie edukacyjno-zawodowym. Dążenie do spójności, współpracy i dobrej jakości. Edukacja Dorosłych, 1, 27-39.

Wojtasik, B. (2011). Podstawy poradnictwa karier. Warszawa: KOWEZiU.

Wojtasik, B. (2012). Podstawy poradnictwa kariery. Poradnik dla nauczycieli. Warszawa: Krajowy Ośrodek Wspierania Edukacji Zawodowej i Ustawicznej.

Wołk, Z. (2006). Całożyciowe poradnictwo zawodowe. Zielona Góra: Oficyna Wydawnicza Uniwersytetu Zielonogórskiego.

Wysocka, E. (2013). Diagnoza pedagogiczna. Nowe obszary i rozwiązania. Kraków: Impuls.

\section{ŹRÓDŁA INTERNETOWE:}

Krakowska Szkoła Doradztwa Zawodowego. Pobrano 23, Sierpnia, 2021 z: pzo.edu.pl Wortal Publicznych Służb Zatrudnienia prowadzony przez Ministerstwo Rozwoju, Pracy i Technologii - aktualna strona: INFOdoradca + Informacje o zawodach. Pobrano 23, Sierpnia, 2021 z: https://psz.praca.gov.pl/rynek-pracy/bazy-danych/ infodoradca 


\section{A CAREER COUNSELOR IN A PSYCHOLOGICAL AND PEDAGOGICAL COUNSELLING CENTER - QUALIFICATIONS AND COMPETENCES}

Introduction: Educational and career counseling has in Poland almost a hundred years of history. The first counseling centers were established in the interwar period, and their main task was to support young people in choosing a profession.

Research Aim: The purpose of this study is to present the activities of a career counselor employed in a psychological and pedagogical counselling center. The article is a review. The primary focus here is on the person of a career counselor (in the context of the formal requirements for this profession, i.e., qualifications, competencies, desired personal characteristics), as well as delineated by the educational law tasks, areas of activity, content, forms, methods, and tools necessary for work in this position.

Evidence-based Facts: The career counselor employed in the psychological and pedagogical counseling center is a specialist in vocational orientation and guidance, assisting primary and secondary school students in planning their educational and career. It is a person with high formal qualifications and competencies (in terms of knowledge and skills), endowed with such desirable personal qualities as openness, kindness, empathy, communication skills, and patience. The counseling process is based on establishing a positive relationship with the client, recognizing the individual's resources (supported by diagnostic testing), and developing an individual action plan (IPD). Professionals' workshop is created according to the provisions of educational law, according to clients' different needs and expectations.

Summary: Supporting the student in educational and professional choices makes the decision-making process more conscious and thoughtful, thus increasing the client's chances of success in future school and work. On the one hand, counseling activities have their specific methodology; on the other hand, they are performed in a very dynamic reality. Therefore, this specialist's knowledge, skills, and workshops must be constantly expanded and updated to meet today's challenges best.

Keywords: career counselor, counseling client, education and career counseling, educational and career choices of young people, professional success, the process of choosing a profession 